\title{
Reaching the Client in Geographically Adverse Conditions: Can Outsourcing Increase Effectiveness and Efficiency?
}

\author{
Christine Westercamp ${ }^{l}$
}

\section{Introduction}

Serving rural financial markets in developing and transition economies requires understanding the specific needs of the rural population in terms of financial products and services, designing adapted products and services on this basis, and defining an adequate organizational set-up.

The specific constraints of the agricultural and rural market induce high costs and risks. In this context, one of the main challenges is setting up adapted and cost-reducing processes, as well as organizational structures. The main issue in this chapter is: How can a financial institution organize the delivery of its services to the agricultural and rural market in a sustainable way?

To answer that question, we will review the specific constraints and costs of providing financial services to remote rural areas, and then discuss how branchless banking can help increase outreach and reduce costs, before concluding on policy recommendations.

\section{Providing Financial Services to Remote Rural Areas: Specific Constraints and Costs}

\subsection{What Are the Constraints Faced in Remote Rural Areas?}

Rural areas in developing countries are not homogeneous. But nevertheless they share a certain number of common challenges in the operating environment impacting the costs, the organizational set-up, and relationship of financial service providers and their clients. ${ }^{2}$ Those constraints can be linked to the environment in which a bank operates or to its clients' characteristics.

\footnotetext{
1 Senior Consultant, Horus - Development Finance.

2 In this paper, the word "bank" is used in a broad sense, to refer to financial institutions offering microfinance services, whatever their regulatory status, thus including microfinance institutions.
} 
Constraints linked to the environment are the following:

- Low population density usually results in higher distances between a bank's branch and its clients, thus increasing transportation costs and time spent in transport, both for the bank's officers and the clients themselves, and offering little opportunities for economies of scale;

- Additionally, poor road infrastructure very often makes access to markets difficult and increases both transportation costs and time spent in transport, for clients, branch staff, as well as head-office staff for supervision and audit missions;

- Lack of access to basic utilities results in higher costs for the bank to run a branch (necessity of a generator, fuel supply, office supplies) and difficulty for the clients to provide copies of documents, photographs, etc. This can potentially be offset by lower costs for renting branch premises;

- Poor communication infrastructure (telephone, internet access) makes it both more complicated to reach clients and more difficult and costly to communicate and update data in the $\mathrm{MIS}^{3}$ resulting in increased risk of fraud and error;

- Cash management is more costly and dangerous, as cash needs to be transported over longer distances, thus reducing frequency and entailing higher levels of liquidity necessary as compared to the level of activity;

- Difficulty of appointing and keeping educated staff in remote places entails higher training and supervision costs;

- When quality of portfolio deteriorates, enforcement costs may be higher in rural areas than in cities with faraway courts and police; moreover, in problematic cases, powerful elders may support customers instead of bank.

Constraints linked to clients' profiles:

- Often lower revenues in rural businesses, linked to typically smaller turnover and size, compared to urban enterprises, lead to lower loan amounts. Typically lower household income and wealth levels lead to lower deposit size per saver. This leads to negative impacts on the net income generated per money unit lent and, respectively, on the cost incurred per money unit deposited;

- Lower use of cash in the rural economy leads to less demand for financial services;

3 "Management information system" is the financial institution's internal management or "back-office" system. 
- Both agriculture and other rural economic activities targeting farmers are seasonal, which makes the banks' cash management more complicated and requires them to adapt loan repayment schedules. The latter may require expensive customization of IT systems;

- Lower financial literacy increases the need to train clients and explain how each product and service works. This needs to be taken into account when designing products and processes;

- In some regions, a bad debt culture has arisen due to failures under the old agricultural credit paradigm.

However some characteristics of rural markets can also be favorable and encourage financial institutions to work there:

- Competition on the financial market is often low, which decreases direct marketing costs and reduces the risks of multiple loans;

- Rural households are usually tied to their land, hence much less mobile than urban households, making borrower monitoring and supervision easier and more reliable;

- In many rural areas, loan repayment discipline is better than in urban areas due to higher social control, reducing the time spent by MFIs in contract enforcement.

\subsection{What Is the Impact of Rural Finance on Cost Structures?}

In the present analysis, the different categories of costs are defined as follows: Production costs are incurred for (and during) the transformation process of the product or the provision of the service. Transaction costs are costs related to using the market for exchange processes (mostly costs of information, establishment of contract and contract enforcement). ${ }^{4}$ Transaction costs are incurred both by vendors and buyers whereas production costs are incurred exclusively by vendors. Specific production and transaction costs incurred for financial services delivery are represented in the diagram in Fig. 1.

A bank might be interested in developing its activities in rural areas in order to spread out its central fixed costs (management, IT, etc.) over a broader base. An analysis of marginal costs and benefits of rural activity can thus be a driver to extension to rural areas.

4 See Erin Andersen, "The Salesperson as Outside Agent or Employee : a Transaction Cost Analysis", Marketing Science, Vol. 4, No. 3, Summer 1985; and Douglass North, Institutions, Institutional Change and Economic Performance, Cambridge University Press, 1990/1999. 
Transaction \& Production Costs for Financial Services Delivery
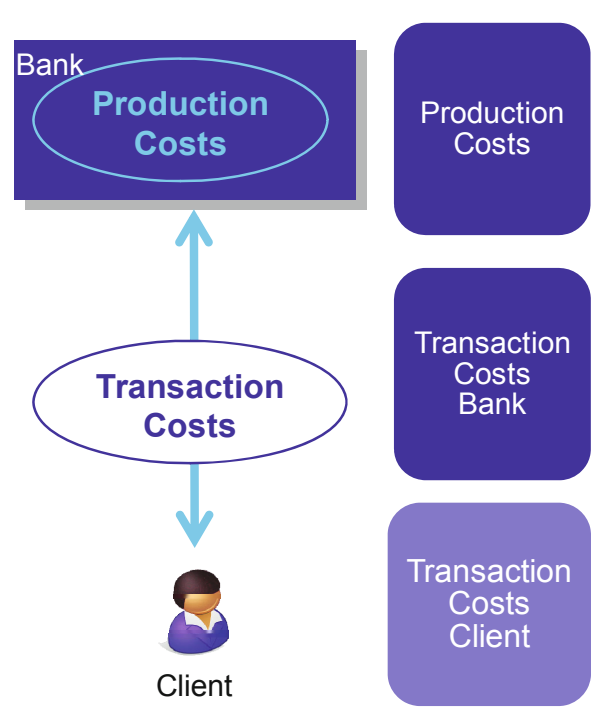

- Infrastructure costs (construction / furniture / IT / safe )

- Staff hiring and training

- Financial resources

- Administration \& management

- Cash management \& securing

- Transactions processing (physical \& CBS)

- Control

- Loan losses

- Market research, promotion

- Distribution

- Loan appraisal (gathering \& managing information)

- Contract negotiation, elaboration and signature

- Contract enforcement: loan monitoring, recovery

- Cash transactions/ information on products and services, on account balance, on left-due on loans ...

- Time \& transportation costs to reach MFI time spent queuing, time spent in meetings

Fig. 1. Transaction and Production Costs for Financial Services Delivery

The central issue in rural finance is the difficulty of reaching clients (the market), without incurring too high costs, both at bank and at client levels. The organizational constraints a bank faces in rural areas require designing different set-ups, processes and products to serve the market in order to lower costs per unit lent for the bank and transaction costs for the client. These client transaction costs are important to consider as they determine a bank's outreach. A detailed analysis of the cost structures of the different types of products and services will help better understand how each of them is impacted by rural market constraints.

\section{Information Costs Are the Main Cost Driver for Lending Operations}

The marginal cost structure of credit delivery from the bank's perspective is mainly composed of transaction costs related to marketing, risk assessment and loan monitoring functions, requiring high staff competencies, and proximity (regular visits and contacts between the bank's qualified staff and the clients). The provision of loans in rural areas requires specific promotion actions aimed at attracting distant clients and at educating them (enhancing their credit culture) with the aim of reducing default risk ex-ante. However, the cost of promotion and loan appraisal strongly decreases in case of renewals, leaving loan monitoring as the main cost-generator. Costs can be lowered on the transaction side by adapting product features (such as group lending, transferring part of the transaction costs from bank to client, standardized products with bullet repayment, etc.), and on the production side by an appropriate 
organizational set-up, which must however take into account the need to maintain regular contact and visits to clients in order to control default risk.

Credit delivery costs also comprise costs related to cash transactions (loan disbursement and repayments). These costs are subject to the same constraints as in the case of other financial services (see below), though less impacted in the case of credit insofar as cash transaction amounts and timing are predictable.

On the client's side, any step of the loan process requiring going to the branch (for loan application, repayments) generates higher transaction costs in rural areas, hence limiting outreach. One of the strengths of the group lending approach in rural areas is that it makes it possible to reduce transaction costs, both for bank and client, in different proportions depending on the processes.

Thus, the main cost of lending in rural areas is information cost, which includes both risk assessment costs - very high for first-time borrowers - and loan monitoring. Marketing is costly but decreases once activity is established. Cash transactions account for a smaller part of costs.

\section{Cash Management Is the Main Cost-Driver for Deposit Services}

The provision of savings and deposit services involves marketing and promotion actions, including the cost of establishing and disseminating a strong image to gain clients' trust, as well as educating clients on savings. Again, this must be done by qualified staff, and is impacted in the same way as for credit services by low population density, poor financial literacy and, in some remote areas, difficulty of keeping qualified staff.

Production costs incurred by the bank in the case of deposits and savings arise from the need to enable cash withdrawals and deposits whenever clients need to and close to their locations (hence lowering the transaction cost for the clients).

Cashier functions involve higher production costs in rural areas for the following reasons:

- (Low) efficiency costs: The number of clients per branch is usually lower, which makes the fixed costs per operation higher. This observation leads to the question of the minimum sustainable number of clients per branch and points out that reasonable occupation of main functions is an important driver of efficiency;

- Security costs: Cash transaction processing outside full-fledged branches is less secured (in the absence of real-time connection to MIS, low security infrastructure, and due to the distance from supervisory and control functions), hence requiring high control costs and generating losses in case of errors or frauds;

- Cash management costs: Transport costs for cash are higher due to longer distances (more hours driving, higher occupation of armed vehicles and related staff, higher number of vehicles needed). Non-secured cash transportation is a common practice but its net cost-impact remains to be determined as it generates risk-related costs. 
Thus, offering deposit and savings services in rural areas involves high production costs mainly related to cashier services. Besides these production costs, the costs incurred to provide clients with information on their accounts and on available products is also affected by larger distances between the bank and its clients.

\section{... as Well as for Remittance and Payment Services}

In the case of remittance and payment services, the main costs are related to cash management, impacted as described above by the rural environment. Exchange of information is critical and may raise costs in rural areas: These services require real-time information exchange (on amounts transferred, on bill amount to be paid, etc.). Clearly, it is the "last mile" of delivering such services that remains the most challenging and the most costly. Thus on the whole, and even more so than in urban settings, microfinance has needed to explore different cost-reduction solutions in order to pioneer financial services delivery in rural areas.

\section{Increasing Outreach Through Branchless Banking}

In recent literature, branchless banking most often refers to "the delivery of financial services outside of bank branches using information and communications technologies and non-bank retail agents, for example, over card-based networks or with mobile phones." In rural finance, different solutions have been experimented with - neither necessarily based on technology nor on external retail agents - to provide financial services outside a branch infrastructure. We will consider all these models in this section, including under the term "branchless banking" both technology-based and non-technology based approaches allowing the delivery of financial services outside conventional bank branches. Let us however underline that, in all cases, the term branchless banking is misleading in that it suggests that branches are irrelevant in these models. The idea is rather one of banking beyond branches, as termed by Alexandre, Mas, and Radcliffe. ${ }^{6}$

Branchless banking models require communication of information on remote operations that can be considerably facilitated by ICTs. ${ }^{7}$ Different technologies can support different types of organization, as presented in Table 1. This paper does not focus on the technologies used but on the different types of organization a bank can set up to bank beyond its branches.

5 See Mark Pickens, David Porteous, and Sarah Rotman, "Scenarios for Branchless Banking in 2020", CGAP Focus Note No. 57, 2009 www.cgap.org/gm/document-1.9. 40599/FN57.pdf (last accessed 16 October 2010).

6 Claire Alexandre, Ignacio Mas, and Daniel Radcliff, "Regulating New Banking Models that Can Bring Financial Services to All", 1 August 2010, http://ssrn.com/abstract= 1664644 (last accessed 16 October 2010) Alexandre et al. (2010). See this paper for a detailed discussion of the concept of "banking beyond branches".

7 Information and Communication Technologies. 
Table 1. Impact of alternative distribution channels on costs per type of product

\begin{tabular}{|c|c|c|c|c|}
\hline $\begin{array}{l}\text { Distribution } \\
\text { Channel }\end{array}$ & $\begin{array}{l}\text { Technology } \\
\text { involved }\end{array}$ & Credit & Deposits and Savings & $\begin{array}{c}\text { Payment and Transfer } \\
\text { Services }\end{array}$ \\
\hline $\begin{array}{l}\text { Mobile } \\
\text { branches / } \\
\text { Periodic } \\
\text { offices / } \\
\text { Small light } \\
\text { offices }\end{array}$ & \begin{tabular}{|l|} 
PDAs, POSs, \\
mobile phones \\
can be used to \\
increase \\
security of \\
transactions
\end{tabular} & $\begin{array}{l}\text { Impact on costs: production } \\
\text { costs per unit and transaction } \\
\text { cost reduced for both FI } \\
\text { (increased staff productivity) } \\
\text { and client } \\
\text { Outreach: outreach remains } \\
\text { limited by long distances / } \\
\text { low population density }\end{array}$ & $\begin{array}{l}\text { Impact on costs: } \\
\text { production costs per unit } \\
\text { and transaction costs } \\
\text { reduced for both FI and } \\
\text { client } \\
\text { Outreach: strongly limited } \\
\text { by distance/ frequency of } \\
\text { office opening }\end{array}$ & Not adapted \\
\hline $\begin{array}{l}\text { Roaming } \\
\text { officers }\end{array}$ & $\begin{array}{l}\text { PDAs, POSs, } \\
\text { mobile phones } \\
\text { can be used to } \\
\text { increase } \\
\text { security of } \\
\text { transactions }\end{array}$ & $\begin{array}{l}\text { Impact on costs: transaction } \\
\text { costs reduced for client } \\
\text { Outreach: increase in } \\
\text { outreach, transactions can be } \\
\text { secured by technology, risks } \\
\text { in case of cash handling, } \\
\text { facilitation of group } \\
\text { technology }\end{array}$ & $\begin{array}{l}\text { Impact on costs: } \\
\text { transaction cost reduced for } \\
\text { client } \\
\text { Outreach: specific service } \\
\text { increasing outreach, } \\
\text { adapted for planned savings } \\
\text { (forced savings / susu) or } \\
\text { densely populated zones }\end{array}$ & Not adapted \\
\hline ATMs & $\begin{array}{l}\text { plastic cards } \\
\text { or mobile } \\
\text { phones and } \\
\text { platform } \\
\text { mandatory }\end{array}$ & $\begin{array}{l}\text { Impact on costs: production } \\
\text { costs per unit and transaction } \\
\text { costs reduced only for cash- } \\
\text { out transactions: loan } \\
\text { disbursement. Maintenance } \\
\text { costs very high } \\
\text { Outreach: not adapted to } \\
\text { remote rural areas - can be } \\
\text { coupled with agents / roaming } \\
\text { officers }\end{array}$ & $\begin{array}{l}\text { Impact on costs: produc- } \\
\text { tion costs per unit and } \\
\text { transaction costs reduced } \\
\text { only for cash-out transac- } \\
\text { tions: withdrawals. Mainte- } \\
\text { nance costs very high } \\
\text { Outreach: increased in } \\
\text { market towns (access to } \\
\text { cash-out and increased } \\
\text { hours of operation) }\end{array}$ & $\begin{array}{l}\text { Impact on costs: pro- } \\
\text { duction costs per unit } \\
\text { and transaction costs } \\
\text { reduced only for cash- } \\
\text { out transactions. Main- } \\
\text { tenance costs very high } \\
\text { Outreach: increased in } \\
\text { market towns (access to } \\
\text { cash-out and increased } \\
\text { hours of operation) }\end{array}$ \\
\hline $\begin{array}{l}\text { MPS } \\
\text { (external) }\end{array}$ & \begin{tabular}{|l|} 
\\
POSs or \\
mobile phones \\
\& platform \\
mandatory
\end{tabular} & $\begin{array}{l}\text { Impact on costs: production } \\
\text { and transaction costs on cash } \\
\text { operations reduced for both FI } \\
\text { and client, net impact depend- } \\
\text { ing on MPS prices. Other trans- } \\
\text { action costs, linked to loan } \\
\text { appraisal and monitoring not } \\
\text { impacted. Possibility to adapt/ } \\
\text { offer more flexibility in prod- } \\
\text { uct processes (e.g. repayment } \\
\text { plans, scaled disbursements) } \\
\text { Outreach: will remain con- } \\
\text { strained by necessity to main- } \\
\text { tain proximity }\end{array}$ & $\begin{array}{l}\text { Impact on costs: } \\
\text { production and transaction } \\
\text { costs strongly reduced by } \\
\text { the outsourcing to external } \\
\text { agents having sustainable } \\
\text { business, for both FI and } \\
\text { client, net impact depending } \\
\text { on MPS prices } \\
\text { Outreach: significant } \\
\text { impact on outreach, secured } \\
\text { transactions, limited risk }\end{array}$ & $\begin{array}{l}\text { Impact on costs: strong } \\
\text { impact } \\
\text { Outreach: possibility to } \\
\text { extend the service range } \\
\text { offered to existing } \\
\text { clients, reach new clients } \\
\text { for such services / } \\
\text { account to account } \\
\text { transfers not possible }\end{array}$ \\
\hline $\begin{array}{l}\text { Mobile } \\
\text { Cashless } \\
\text { Services } \\
\text { (no cash } \\
\text { transactions) }\end{array}$ & mobile phones & $\begin{array}{l}\text { Impact on costs: transaction } \\
\text { costs slightly reduced } \\
\text { (information request, } \\
\text { installment reminder...), for } \\
\text { both FI and client } \\
\text { Outreach: no impact on } \\
\text { outreach }\end{array}$ & $\begin{array}{l}\text { Impact on costs: transaction } \\
\text { costs reduced only for non } \\
\text { cash operations (account to } \\
\text { account transfers, push and } \\
\text { pull information), for both FI } \\
\text { and client } \\
\text { Outreach: will remain } \\
\text { constrained by the necessity } \\
\text { to offer easy access to cash } \\
\text { transactions }\end{array}$ & $\begin{array}{l}\text { Impact on costs: transac- } \\
\text { tion cost reduced only for } \\
\text { non cash operations (ac- } \\
\text { count to account trans- } \\
\text { fers, information) } \\
\text { Outreach: will remain } \\
\text { constrained by the neces- } \\
\text { sity to offer easy access to } \\
\text { cash transactions }\end{array}$ \\
\hline $\begin{array}{l}\text { MB } \\
\text { (internal) }\end{array}$ & \begin{tabular}{|l|} 
POSs or \\
mobile phones \\
and platform \\
mandatory
\end{tabular} & $\begin{array}{l}\text { Impact on costs: see MPS, } \\
\text { but prices are internal costs + } \\
\text { SMS } \\
\text { Outreach: will remain } \\
\text { constrained by necessity to } \\
\text { maintain proximity }\end{array}$ & $\begin{array}{l}\text { Impact on costs: see MPS, } \\
\text { but prices are internal costs } \\
+ \text { SMS } \\
\text { Outreach: significant } \\
\text { impact on outreach, secured } \\
\text { transactions, limited risk }\end{array}$ & $\begin{array}{l}\text { Impact on costs: strong } \\
\text { impact } \\
\text { Outreach: possibility to } \\
\text { extend the service range } \\
\text { offered to existing } \\
\text { clients, reach new clients } \\
\text { for such services }\end{array}$ \\
\hline
\end{tabular}


An analysis of different branchless banking models will help us understand how cost efficiency can be enhanced. We will differentiate between internal solutions for branchless banking from solutions partly or entirely relying on outsourcing, as the issue of outsourcing raises specific questions. We will also differentiate between financial products and services when relevant.

\subsection{Branchless Banking: Banks' Internal Solutions}

In rural areas, banks have long set up alternative delivery channels to provide financial services outside full-fledged branches at lower costs.

\section{Low-Cost Retail Outlets}

Alternative retail outlets have been set up in rural areas that reduce both production and transaction costs while offering the same services as full-fledged branches:

- Setting up small-sized offices with lighter infrastructure ${ }^{8}$ but providing a full range of services: In this case, fixed production costs remain relatively high since minimum equipment remains necessary to handle cash. The level of cash to be maintained to avoid cash shortage also remains high as do all transaction costs related to promotion, loan assessment and monitoring (because of the low concentration of clients). Overall, the reduction in transaction costs for the bank depends on the geographic concentration of clients in the office's area;

- Having such offices open only one or two days per week (market day, etc.) allows a better allocation of staff resources (both cashiers and loan officers, LOs), who can cover several areas. ${ }^{9}$ This however reduces quality of service;

- Mobile retail outlets, using vehicles such as buses: ${ }^{10}$ fixed production costs may be significantly reduced compared to the first two solutions, while the

8 Numerous examples among which PADME in Benin, FCPB in Burkina Faso, BNDA in Mali, Opportunity International Malawi (see Bryan Campbell and Aleksandr-Alain Kalanda, "Banking Rollout Approaches to Rural Markets - Opportunity International Bank of Malawi", OI White Paper $N^{\circ} 8,2008$, as well as the famous 4-staff units of BRI in Indonesia.

$9 \quad \mathrm{Al}$ Amana in Morocco and BNDA in Mali, for example, have set up periodic offices in rural areas opening on market days.

10 ProCredit Moldova, for instance, operates three mobile offices in the northern, central and southern parts of the country in order to maximize geographical coverage. See ProCredit Bank Moldova, Annual Report 2009, www.procredit-holding.com/front content.php?idcat=26 (last accessed 16 October 2010), p. 24.

Al Amana in Morocco also operates 35 mobile offices in its scattered rural credit program and plans to increase this number (own field work, Sept. 2010); precise cost analysis will be set up and interesting to follow. Other banks (e.g. CNCA Morocco) have stopped using mobile offices following cost analysis. 
service range offered to the clients is similar to that of the previous solution. However, higher operational costs and security (of cash and of staff) may offset the savings in investment costs, depending on context.

In the three models presented above, portable equipment such as personal digital assistants (PDAs) or point of sales devices (POSs) can be used to secure transactions at reasonable investment costs. However, access to a telecommunication network to ensure real-time or daily transfer of information can be an issue in some remote rural areas.

\section{Alternative Delivery Method: Roaming Officers ${ }^{11}$}

One of the most widespread solutions to reach rural areas consists in having roaming officers going into the field to perform transactions such as account opening, application registration, loan appraisal and monitoring, and possibly cash transactions. Such an organization significantly reduces costs: client-transaction costs, but also bank-transaction, and production costs. Cost-efficiency will depend on the number of clients that a roaming officer is able to serve (hence depending on population density and transportation infrastructure).

Roaming officers are usually dedicated to credit (possibly associated with compulsory savings linked to credit) and/or to on-the-field savings collection. ${ }^{12}$ However, in the case of savings collection, frequency highly impacts transaction costs or limits outreach, so that it might not be cost-effective in remote rural areas. Withdrawals as well as transfer and payment services are difficult to offer through roaming officers, as (i) they would require the officers to transport larger cash amounts, and (ii) they require real-time information access to the bank's MIS.

Main issues to be addressed are how to secure cash and transactions, and to ensure staff safety:

- When transactions are done manually (using vouchers), the level of risk is very high, though it can be reduced by appointing a team of two people, one being in charge of transactions registration, the other of cash handling;

- Transactions can be better secured when agents are equipped with PDAs, POSs or mobile phones connected to the MIS (see below), which however are strongly dependent on access to telecommunication networks.

11 The term "roaming officers" has been preferred here to that of "mobile officers", which could have been misleading in a discussion around mobile banking in which mobile often refers to mobile phones.

12 SafeSave in Bangladesh used roaming officers equipped with PDAs to collect cash on the field, both for credit repayment and savings: roaming officers called clients on a regular basis, offering them to come and collect cash if needed. 
Roaming officers have thus proven to be an efficient solution to increase outreach in rural areas, mainly for credit and sometimes savings collection. Security and risk issues are however to be addressed, possibly with the help of modern technologies.

\section{Staffless Delivery Channel: ATMs}

Implementation of stand-alone ATMs in rural areas helps to secure cash transactions at reduced production and transaction costs, although investment and cash management costs remain high making it profitable only if a minimum number of transactions per time unit is ensured. They are an option for withdrawals, loan disbursements, informational purposes and transfers between accounts but, in many contexts, cash-in operations seem difficult to offer, as banknotes are often damaged, hence not recognizable by ATMs.

Use of ATMs reduces staff costs. Investment and maintenance costs, however, remain relatively high, as well as cash management and transportation costs. Additionally, using stand-alone ATMs in rural areas faces a number of limitations: a permanent connection and power supply are required, maintenance is much more costly due to distance and repair more complicated and suffering longer delays. As a consequence, if the number of transactions is low, ATMs might prove too expensive in rural areas.

Opportunity International, which launched a program in Malawi including the implementation of high-tech ATMs in particular in rural areas, concluded three years later that serving the poor in rural areas is much more challenging from an infrastructure standpoint than in the urban areas. They have taken measures to reduce ATM costs:

- Switching from smartcards to magstripe cards, reducing the cost per card;

- Moving the biometrics from the smartcard to the switch;

- Placing ATMs in locations with the highest traffic levels and then using merchant agents for other market areas that don't justify the cost;

- To address education, utilizing the guard who is watching the ATM to handle customer training - by using biometrics, this is a low risk approach to getting the customers educated; while customers are often illiterate they are not innumerate and with some guidance, they catch on pretty quickly. ${ }^{13}$

Thus, having ATMs available in market towns, combined with roaming officers and third-party agents (see part 2.2.), might be an interesting solution to provide a full range of services and reduce risks and costs linked to cash transportation.

13 From e-mail exchange with Daryl Skoog, Chief Technology Officer at Opportunity International Network, Oct. 2010. See also Campbell et al. (2008). 


\section{SMS Information Services to Facilitate Data Exchange}

Mobile phones can make it easier to exchange data with clients at reduced costs: information can easily be provided by SMS, both on request of the client ("pull"): account balances, mini statements, amount due, etc., and sent by the bank ("push"): installment reminder, new services available, invitation to meetings, etc. This implies a reasonable investment cost depending on the MIS (a light application has to be added) and transaction costs usually remain low (see Table 3 ).

Table 2. Elements of Costs for Different Technologies

\begin{tabular}{|c|c|c|c|c|c|c|}
\hline & \multicolumn{2}{|c|}{ entry cost (system set-up) } & \multicolumn{2}{|c|}{ cost of each additional device } & \multicolumn{2}{|r|}{ transaction cost } \\
\hline PDA & $* *$ & $\begin{array}{l}\text { - requires specific } \\
\text { developments to } \\
\text { "mobilize" part of the } \\
\text { CBS application } \\
\text { - requires an in-depth } \\
\text { market research to } \\
\text { select the technology } \\
\text { an devices }\end{array}$ & $* *$ & & $*$ & \\
\hline $\begin{array}{l}\text { POS - } \\
\text { internal }\end{array}$ & $* * *$ & & * & & * & \\
\hline $\begin{array}{l}\text { mobile } \\
\text { payment - } \\
\text { external }\end{array}$ & $* *$ & $\begin{array}{l}\text { - moderate: connexion } \\
\text { between Telco \& FI } \\
\text { MISs for bill payment } \\
\text { - moderate }+ \text { : for } \\
\text { account information \& } \\
\text { transfer from / to } \\
\text { account }\end{array}$ & $\begin{array}{l}\text { (neg- } \\
\text { ligi- } \\
\text { ble) }\end{array}$ & - & $* *$ & can be high \\
\hline $\begin{array}{l}\text { mobile } \\
\text { payment - } \\
\text { internal }\end{array}$ & $* * * *$ & $\begin{array}{c}\text { - high: specific MB soft } \\
\text { + connexion to Telco } \\
\text { system + promotion }\end{array}$ & $*$ & $\begin{array}{l}\text { unit cost of agent } \\
\text { management }\end{array}$ & $*$ & $\begin{array}{l}\text { cost of SMS sent by the } \\
\text { FI Beware, some } \\
\text { providers ask for an } \\
\text { annual fee per active } \\
\text { customer }\end{array}$ \\
\hline $\begin{array}{l}\text { SMS- } \\
\text { banking } \\
\text { only }\end{array}$ & $* *$ & & 0 & - & & $\begin{array}{l}\text { cost of SMS sent by the } \\
\text { FI }\end{array}$ \\
\hline $\begin{array}{l}\text { ATM-self- } \\
\text { supported } \\
\text { by the FI }\end{array}$ & $* * *$ & $\begin{array}{l}\text { - cards system software, } \\
\text { interfaced with CBS } \\
\text { - Set-up fee to install } \\
\text { and network the } \\
\text { ATMs }\end{array}$ & $* * * *$ & $\begin{array}{l}\text { unit cost of each ATM } \\
(+ \text { installation }+ \\
\text { maintenance... }\end{array}$ & $* *$ & $\begin{array}{l}\text { - costs depend on the } \\
\text { nature and volume of } \\
\text { cards issued } \\
\text { - costs of refilling } \\
\text { ATMs with cash... }\end{array}$ \\
\hline $\begin{array}{l}\text { ATM - } \\
\text { joining an } \\
\text { existing } \\
\text { network }\end{array}$ & $* *$ & $\begin{array}{l}\text { - network participation } \\
\text { fee } \\
\text { - Set-up fee to install } \\
\text { and network the } \\
\text { ATMs } \\
\text { - interface with CBS }\end{array}$ & $* * *$ & $\begin{array}{l}\text { unit cist of each ATM } \\
(+ \text { installation+ }+ \\
\text { maintenance...) }\end{array}$ & $* *(*)$ & $\begin{array}{l}\text { Usage fee, either per } \\
\text { transaction or on a } \\
\text { monthly basis } \\
\text { Careful: if Visa (or other } \\
\text { international network): } \\
\text { investment may be lower } \\
\text { but transaction fees are } \\
\text { hefty! }\end{array}$ \\
\hline
\end{tabular}

Source: Horus estimates 
Table 3. Stylized cost structure of $1 \mathrm{G} \& 2 \mathrm{G}$ Banking Models

\begin{tabular}{|c|c|c|c|c|}
\hline & & Branch-based (1G) & $\begin{array}{c}\text { POS-based agent } \\
\text { banking (2G) }\end{array}$ & $\begin{array}{c}\text { Cell phone-based agent } \\
\text { banking }(2 G)\end{array}$ \\
\hline \multirow{4}{*}{$\begin{array}{l}\text { Fixed costs } \\
\text { per outlet }\end{array}$} & $\begin{array}{l}\text { Start-up cost per } \\
\text { outlet }\end{array}$ & $\begin{array}{l}\$ 100,000 \text { Office setup } 7 \\
\text { conditioning, computer } \\
\text { equipment, security, etc. }\end{array}$ & $\begin{array}{l}\$ 2,000 \text { Installation } \\
\text { including POS terminal, } \\
\text { communications line, } \\
\text { training \& marketing }\end{array}$ & $\begin{array}{l}\text { \$500 Training \& } \\
\text { marketing only; no } \\
\text { equipment cost }\end{array}$ \\
\hline & Useful life & 10 yrs. & 3 yrs. & 3 yrs. \\
\hline & $\begin{array}{l}\text { Operating cost per } \\
\text { month per outlet }\end{array}$ & $\begin{array}{l}\$ 8,00010 \text { salaries, rent, } \\
\text { office maintenance }\end{array}$ & $\begin{array}{c}\$ 300 \text { Equipment } \\
\text { maintenance \& supplies } \\
\text { (e.g. paper, marketing } \\
\text { materials) }\end{array}$ & $\begin{array}{l}\text { \$50 Marketing materials } \\
\text { only }\end{array}$ \\
\hline & $\begin{array}{l}\text { Maximal transaction } \\
\text { per outlet per month }\end{array}$ & $\begin{array}{c}\$ 18,0007 \text { teller, each } \\
\text { doing } 10 \text { transactions per } \\
\text { hour, } 8 \text { hours per day, } 5 \\
\text { days/week }\end{array}$ & $\begin{array}{c}\$ 3,0001 \text { terminal, } 10 \\
\text { transactions per hour, } 10 \\
\text { hours per day, } 30 \text { days } \\
\text { per month }\end{array}$ & $\begin{array}{l}\$ 3,000 \\
\text { Ditto }\end{array}$ \\
\hline \multirow{2}{*}{$\begin{array}{l}\text { Variable } \\
\text { cost per } \\
\text { transaction }\end{array}$} & $\begin{array}{l}\text { Communications cost } \\
\text { per transaction }\end{array}$ & $\begin{array}{l}\text { \$0.01 Minimal charge } \\
\text { for uploading from IT } \\
\text { system }\end{array}$ & $\begin{array}{l}\$ 0.05 \text { The equivalent of } \\
1 \text { SMS per transaction }\end{array}$ & $\begin{array}{l}\$ 0.15 \text { The equivalent of } 3 \\
\text { SMSs per transaction }\end{array}$ \\
\hline & $\begin{array}{l}\text { Agent commission per } \\
\text { transaction }\end{array}$ & $*$ & $\$ 0.10$ & $\$ 0.10$ \\
\hline \multirow{3}{*}{$\begin{array}{l}\text { Fixed cost } \\
\text { per new } \\
\text { customer }\end{array}$} & $\begin{array}{c}\text { Customer acquisition } \\
\text { cost }\end{array}$ & $\begin{array}{l}\text { \$5.00 Cost of handling } \\
\text { directly at branch }\end{array}$ & $\begin{array}{c}\$ 2.00 \text { Procession cost \& } \\
\text { sign-up commission paid } \\
\text { to agent }\end{array}$ & \$2.00 Ditto \\
\hline & $\begin{array}{l}\text { Customer credentials } \\
\text { (card) }\end{array}$ & $\begin{array}{c}\$ 5.00 \text { Half the customers } \\
\text { get a bank card }\end{array}$ & $\begin{array}{l}\$ 10.00 \text { Card issuance } \\
\text { and maintenance costs }\end{array}$ & $\begin{array}{l}\% 0.20 \text { Over the air } \\
\text { configuration of phone }\end{array}$ \\
\hline & $\begin{array}{l}\text { Average customer } \\
\text { lifetime }\end{array}$ & \multicolumn{3}{|c|}{36 month } \\
\hline $\begin{array}{l}\text { Back-office } \\
\text { costs }\end{array}$ & $\begin{array}{l}\text { Back-office cost per } \\
\text { customer per month }\end{array}$ & $\$ 0.30$ & $\$ 0.30$ & $\$ 0.30$ \\
\hline \multicolumn{2}{|c|}{ Revenue to bank } & \multicolumn{3}{|c|}{$4 \%$ p.a. interest spread $+\$ 0.50$ per transaction } \\
\hline \multicolumn{2}{|c|}{$\begin{array}{l}\text { Customer costs per transaction } \\
\text { (not borne by provider) }\end{array}$} & $\begin{array}{l}\$ 0.50 \text { bus ticket }+2 \\
\text { hours travel \& queuing } \\
\text { time }\end{array}$ & 30 minutes total time & 30 minutes total time \\
\hline
\end{tabular}

Source: Mas (2009) - all figures in USD

All of these different delivery channels developed internally by banks significantly reduce transactions costs for clients, hence increasing access. They however often induce significant production costs for banks unless a minimum concentration of clients is achieved. Their adequacy therefore very much depends on context.

\subsection{Branchless Banking: How ICT Boosted Outsourcing Possibilities}

In many sectors of activity, selling products and services through external distribution networks is a very common way for producers to reduce transaction costs. Although some banks have been performing transactions with clients outside of 
branches using third-party agents for a long time, ${ }^{14}$ ICT opens new possibilities for this type of partnerships between banks and agents (whether existing networks or networks set up by the bank itself). We will first look at information flows allowing outsourcing of transactions, then at what can be outsourced.

\section{Information Management}

In order to outsource a transaction, a bank needs to communicate data from its MIS to the third-party agent who is going to perform the transaction on its behalf and, after completion of the transaction, from the agent to the bank's MIS. Although an online connection is preferable, it is also possible to operate with periodic batch transactions or even transmission of paper information that will need to be entered manually in the bank's MIS. ${ }^{15}$ This reflects the reality of many rural MFIs' outlets, ${ }^{16}$ either for connectivity reasons (technical or cost) or because of the limitations of their MISs (in some cases, all outlets are not computerized and data capturing is done in a remote office based on paper documents).

Security of transactions is tremendously increased by automatic entry of data in the bank's MIS, which ensures exhaustivity of data and integrity of processes. This opens the possibility of working with independent agents who could not be monitored closely enough without automation of transactions. On-line connection is moreover indispensable for some types of transactions (immediate withdrawal from bank account, for example).

\section{What Can Be Outsourced?}

Different functions are outsourced in different banks. The functions that can be outsourced include: ${ }^{17}$

- Cash transactions linked to money transfers, payments (including bills, retirement and social benefits, salaries, mobile phone airtime top up, insurance services), and cash transactions to/from bank accounts (loan disbursement, loan repayment, deposit taking, deposit withdrawal);

- Communication with bank (balance enquiry, mini-bank statements, cheque book request). This can also be done through simple SMS;

14 As PADME in Benin at its beginnings with Financial Bank, FIDES in Namibia with Postal network, also in developed countries financial advisors canvassing clients to sell banks' financial products.

15 This is the case of many MFIs working with post offices, as Finadev in Benin or FIDES in Namibia.

16 This is the case, for example, of most of Morocco's small and medium-sized MFIs and of AMRET in Cambodia until recently.

17 See Central Bank of Kenya, Guidelines for Agency Banking (2010) and Reserve Bank of India: Circular Financial Inclusion by Extension of Banking Services - Use of Business Facilitators and Correspondents, http://rbi.org.in/scripts/BS_CircularIndexDisplay. aspx?Id=2718. 
- Client management (opening of deposit or savings accounts, collection and preliminary processing of loan applications, promotion and nurturing of joint liability groups, loan follow-up and post-sanction monitoring).

Outsourcing the latter two kinds of transactions however requires specific skills that all agents are not necessarily capable of acquiring and that entail accrued training and supervision costs. The most critical to enhance outreach and the easiest to outsource are cash transactions.

Certain critical steps in the lending process cannot be outsourced, namely (i) risk assessment, except in cases where enough information is available to use a credit scoring model, ${ }^{18}$ (ii) loan monitoring, and (iii) loan recovery. All three are key to control portfolio quality.

One important issue is safety and confidentiality of the client's financial operations. In order to protect it, agents must meet defined material requirements. On top of this, some systems confine agents to a role of "ignorant tellers"19 i.e. tellers who cash in or out without knowing what operation a client is coming for, the system only sending them the information they need: "please cash out $\$ 10$ to Ms. Xxx" / "please cash in \$5 from Mr. Yyy". This leaves it to the client to decide whether or not he wants his agent to know what operation he is handling. Another advantage with such a system is that qualifications required from an agent are very low: it is sufficient that he is honest and trustworthy, numerate, able to count money and manage his cash needs; if he is to do other than cash operations, he will need to be able to read and write.

\subsection{Branchless Banking: Different Types of Partnerships}

\section{Outsourcing by Partnering with Existing Financial Institutions}

The idea of teaming up with existing networks of financial services providers to deliver a bank's services is not new: It has been successfully implemented for years by many credit-only MFIs to supply credit services. ${ }^{20}$ In countries where a reliable bank or post network reaches deep enough in rural areas, partnering with it for cash management reduces the infrastructure that is necessary for the MFI's activity: loans can be disbursed through checks or transfers to account if the client has an account with the partner-bank, and repaid at the partner-bank's tellers. In some cases, the transactions are supported by POS devices and plastic cards to facilitate transfer of information to the MFI's MIS.

Results from experience show that this type of partnership is an effective way of cutting costs for credit-only MFIs but can be subject to limitations:

18 As planned by for M-Kesho in Kenya.

19 This is the case, for example, of Noomadic at Xacbank Mongolia.

20 Further examples: Tadjik MFIs IMON and Humo with Agroinvestbank, Kenyan MFIs with different banks. 
- Partner's capacity/willingness to serve the MFI's clients with the required level of quality;

- Possible competition between the MFI and its partner in delivering similar services (partner might use its knowledge of the MFI's clients to open a competing service; MFI cannot use the partnership to supply those services which the partner himself already offers).

\section{Outsourcing by Partnering with Existing Mobile Payment Systems}

In an increasing number of countries, mobile payment services (MPS) are available on the market: We hereby refer to systems in which a non-bank institution has set up a technical platform processing electronic transactions and a network of agents handling cash transactions. These services are very often based on mobile phones, the best-known being M-PESA, but can also be card-based, as is the case of e-zwich in Ghana (see Box 1 for clarification of the different notions linked to "mobile banking"). In these cases, clients hold an account with the MPS provider (e-wallet), where they can store value (known as e-money) to pay for services (bills, airtime) or to transfer money or airtime (to friends, relatives, business partners).

As compared to accounts in banks, e-wallets at MPS providers' have larger outreaches as they are more easily accessible (account opening procedures and knowyour-customer regulations are usually lighter for such accounts), and are often operated by Mobile Network Operators (MNOs) with huge existing networks and marketing power. Proximity thus makes it possible to strongly reduce transaction costs for clients. However, e-wallets cannot be a substitute for bank savings accounts as, typically, due to regulation, their balance is capped and no interest can be paid on the e-money stored. Hence, the possibility to make transfers from an ewallet to a bank account at a reasonable cost is important if e-wallets are used to facilitate savings services.

Possible partnerships between MPS providers and banks consist in:

- Easiest and most frequent: using clients' e-wallets as transit accounts to conduct cash-in transactions to the bank (loan repayment and in some cases deposit on savings account), most frequently using the bill payment function of the MPS. ${ }^{21}$ This is generally not done based on an online connection between MPS provider and bank but on a daily batch transfer of funds and related information. A significant advantage as compared to partnering with another financial institution is that the data is directly transferred to the bank's MIS without need for re-entry with the costs and risks associated.

This can lead to a significant reduction in transaction costs: (i) for the client as compared to going to his bank branch or a partner bank branch or (ii) for the bank as compared internally processing cash transactions or to

21 The best-known example is M-PESA, with Faulu, SMEP and KWFT, see Anjali Kumar, Ajai Nair, Adam Parsons, Eduardo Urdapilleta, "Expanding Bank Outreach through Retail Partnerships, Correspondent Banking in Brazil”, World Bank Working Paper No. 85, 2006. 


\section{Box 1: Clarification of the Different Notions Linked to "Mobile Banking"}

Mobile banking consists in offering financial services to consumers through their mobile phones. The term is also sometimes used for remote transactions based on other technologies (e.g. plastic cards and POS devices).

Several distinct notions are often included under the words "mobile banking":

- "Information services": exchange of financial information, initiated:

- By a financial institution ("push"): alert, transaction receipt, marketing message;

- By the client ("pull"): balance inquiry, request for statement.

- Mobile payments: person-to-business payments that are made with a mobile phone:

- Non-cash payment of goods at merchants

- Payment of bills (cash or non-cash)

- Repayment of loans to a bank or MFI

- Mobile money transfers: person to person transfer (requires cash transactions to deposit and collect the money transferred)

- Mobile banking (narrow definition): connecting a mobile phone and an account in a bank, to allow customers to use the mobile phone as another channel to access financial services:

- Deposits / withdrawals on current account

- Information services

- Mobile payments

- Mobile transfers (both cash and account to account)

the LO collecting the funds; depending on the MPS prices, the costreduction will cover the commissions or not. The bank's costs can also be impacted in the case of group-lending by a reduction in the time spent in group meetings that can lead to higher LO productivity, thus reducing transaction costs per loan. Effective increase in the productivity of a LO will very much depend on the context;

- Integrated offer, by which clients can access their bank account and other services through the MPS in real-time, either for cash-in or for cash-out. Some systems work only with one bank account (M-Kesho Kenya associating M-PESA and Equity Bank ${ }^{22}$ ), others can link several accounts to one

22 In May 2010, M-PESA and Equity Bank in Kenya announced the most integrated product offering so fara low-cost, low-entry microsavings account called M-Kesho. With this account, Equity Bank hopes to convert the majority of M-PESA's 9.4 million users into account holders at the bank and plans to offer microinsurance and microloans in 
mobile phone, i.e. current account, savings account, loan account (Tameer/ Telenor in Pakistan) or offer transfers from e-wallet to any bank account. M-Kesho also opens access to a personal accident insurance policy and, once six months of transaction data are available, an instant loan product based around a credit scoring model. ${ }^{23}$

Thus, using an existing external mobile payment system that channels cash to the bank can lead to significant reductions in transaction costs, both at client and at bank levels, which make it possible to increase outreach for deposit and savings services and also sometimes for loans. In this case, outsourcing is necessarily limited to cash transactions.

\section{Conditions to Increase Outreach Through Partnering with Financial Services Providers}

Let us look further into the impact of critical elements on the success of a bankfinancial services provider partnership: price, place and information exchange.

A change in the pricing of a partner financial services provider will have immediate repercussions on the bank's transaction costs and, depending on its scale, a bank is not always in a position to negotiate, be it with post or MNOs. Concerning mobile payment networks, Kenyan MFI clients ${ }^{24}$ found M-PESA charges inferior to their previous transportation costs, which was critical to their adoption of the system; however this cannot be generalized as Kenyan MPS prices are much lower than those of MPS providers in other countries ${ }^{25}$ and this type of partnership often fails because of the difficulty of defining an economic model that is satisfactory for both the MPS provider and the bank. ${ }^{26}$

addition to savings accounts. Very few institutions have the negotiating power of Equity Bank to achieve this, but this joint venture has the potential to extend access to formal financial services to millions of currently unbanked individuals. M-PESA has since replicated this agreement with other banks and Equity Bank launched a one-year exclusive partnership with Orange's Iko-Pesa in November which it plans to replicate in neighboring Uganda, Tanzania, and Rwanda.

23 In Claudia McKay, "From rural outpost to boomtown: How banking services transformed a town in the Amazon", CGAP technology blog, 2010 the author describe sixs "New Products Riding the M-PESA 'Rails"”.

24 See Kumar et al., 2010.

25 This is the result of a benchmarking done by Horus Telecom and Utilities. The reasons for this difference in costs are not clear; they should certainly be related to the volume of operations and the competition on the Kenyan mobile banking market, also to an aggressive pricing strategy aiming at encouraging clients to test and use the novel mobile payment services, and to DFID's support which led to setting up a small, autonomous and highly motivated team to manage the launching of M-PESA.

26 Orange in Senegal, for example, partnered with PlaNet Finance since 2008 with a support from the Bill and Melinda Gates Foundation to set up partnerships with MFIs. But the program failed due to the difficulty of coming to an agreement between MFIs and MNO on the business model. 
The agent network's coverage is also a point that appears critical. In rural areas especially, different mobile payment networks might not cover the same areas and the financial capacities of the MPS provider's agent network might not be sufficient to cover the amounts needed for the bank's transactions. Thus, before entering into an agreement with an MPS provider, a bank needs to make sure that its agent network will be capable of delivering the services necessary, both geographically and financially.

A limitation that appears in most partnerships between banks and existing financial services providers is that technical reasons make it difficult to take into account changes in the amount of a loan repayment (interests on delay, late penalties, indexation), for reasons linked to the communication format with the partner institution, or to the software used in case of mobile payments, the billing function not being designed for financial products. The introduction of POSs can be a solution to explore if cost is bearable by the activity. ${ }^{27}$

Whereas partnering with existing financial institutions is clearly in most cases not adapted for savings because it would compete with the partner financial institution's services, as we have seen partnering with a mobile payment system can in some cases allow access to savings or current accounts. However, the ease of transfer from e-wallet to bank account and its cost will be decisive to effective use of the service.

It thus appears that the impact on outreach and transaction costs of partnering with financial services providers for the delivery of a bank's services varies, depending on the price of the agents' services, the adequacy of the agent network for the bank's clientele and the specificities of the bank's products.

\subsection{Setting Up a Bank-Led Mobile Banking System}

For a bank, setting-up its own mobile banking system basically consists in outsourcing teller activities to external cashiers holding an account in the bank. Just as with an MPS provider, authentication and registration of transactions can be done by mobile phone or by card. This will result in a bank-led mobile banking system (for a synthesis of the differences between bank-led and non-bank-led mobile banking schemes, see Box 2). The major difference with a MPS is the fact that there is no e-wallet: the bank-led MB is an additional distribution channel to access bank accounts, which are therefore much more easily accessible. ${ }^{28}$ The main advantages for banks of setting up their own MB are:

- It contributes to promoting savings, as it gives the clients easy access to money on their deposit account and increases transparency through SMS information;

- Bank sets pricing according to its own interests;

27 FIDES Namibia is contemplating this solution in its partnership with the postal network.

28 As for example Xacbank Mongolia, Opportunity Bank Malawi, see Kumar et al. (2010), Cajas Vecinas Chile. 
- Banks determines the product range with financial services eyes; ${ }^{29}$

- Bank-led schemes are potentially open to customers of all mobile operators (provided the bank negotiates agreements with these operators);

- The money "stays in the bank" whereas with non-bank solutions involving e-money, the float (total value of e-money issued) goes to a financial institution not necessarily interested by a small rural clientele;

- Cross-selling effects are easier to create, for example clients coming to save can build up a history of transactions which can be taken into account for future loan appraisals.

\section{Box 2: Differences Between Bank-Led and Non-Bank-Led "Mobile Banking"}

Mobile banking schemes are often classified with reference to the promoter of the system:

- Bank-led scheme (corresponding to our narrow definition of mobile banking):

- Client has a contract with a regulated financial institution;

- Mobile banking is used by the financial institution as an additional channel to distribute existing financial services outside of its branches;

- Mobile banking transactions are made directly on the client's current account.

- Non-bank-led scheme (this is what we refer to here as mobile payment services):

- Client has a contract with a non-financial institution (Mobile Network Operator, Payment service provider...);

- Clients exchange money for a stored electronic value ("e-money") that they can use to pay goods and services or transfer to another account holder;

○ E-money is stored on a specific account, called "virtual account," "electronic wallet."

29 See: McKay et al., 2010: "MNOs, which have often led the first wave of innovation in branchless banking in some countries, are not well positioned on their own to lead a new wave if it entails offering a broader range of products. Finally, some MNOs will find mobile payments do everything they want them to do: increase loyalty among voice clients and decrease the cost of distributing airtime. In other words, they may have no motivation to do more", p.10. 
We will now look at third-party agents, discuss the critical success-factors of dealing with the principal-agent dilemma and managing cash, and then explore the challenges that need to be met in order to set up a third-party agent network.

\section{Who Are Third-Party Agents?}

Third-party agents are existing commercial outlets that can be very varied: village shops, pharmacies, gas stations, lottery kiosks, cybercafés, post offices, MFIs, ${ }^{30}$ etc. As a prerequisite for being a financial institution's agent, they must have an activity involving cash transactions and be ready to manage a sufficient level of funds; moreover, their existing activity should cover their fixed costs. As agents typically incur very few specific fixed production costs for offering the banking services, except for the necessity of maintaining a sufficient level of float (see below), the fact that the contribution of their agent revenue is marginal dramatically reduces the break-even point related to the provision of financial services. As a consequence, they have the capacity of reaching out much further than bank branches.

\section{The Bank - Agent Relationship}

A challenge to successful outsourcing is the management of the principal agent problem, i.e. the difficulties that arise when a principal hires an agent, such as the problem of potential moral hazard and conflict of interest, inasmuch as the principal is - presumably - hiring the agent to pursue its, the principal's, interests.

The benefit a shopkeeper can expect from becoming an agent is not only financial (from the commissioning). Other important aspects are: increasing visibility, attracting new customers with cross-selling effects, and making better use of existing infrastructure and available staff time. Reciprocally, the agent's image will impact the bank's: a bank partnering with well-established agents will gain in visibility and potentially attract new clients, whereas partnering with agents having a bad reputation will jeopardize the bank's image. The way agents treat the bank's customers will also reflect on the bank's reputation. Moreover, in cases where the agent also delivers financial services other than those of the bank, conflict of interest arises.

All these elements need to be taken into account when choosing agents and defining the economic model, the contract and the monitoring system so as to bring the agent's interests into alignment with the bank's interests and to be able to adjust quickly if necessary.

30 Central Bank of Kenya, for example, has issued guidelines for agency banking in May 2010, including the possibility for MFIs and SACCOs to act as banking agents. 


\section{Managing the Cash}

Cash management is the critical aspect of the agent business. We will now look at how this is handled in various contexts. The main obstacles agents meet in this regard are:

- Employee malfeasance, as store owners must almost always leave a large amount of money in the hands of employees in order to rebalance their float;

- Physical security;

- Travel cost and time, which has to be factored in the analysis of the profitability of the financial services activity for the agent. ${ }^{31}$

The total amount of transactions external agents can operate as well as the unit amounts they will be authorized to handle will be limited by their financial capacities: typically when working with small independent agents, cash transactions are offset by corresponding transactions in the agent's account at the bank, whereby the agent is only authorized to receive cash up to the amount available on his account (float) - when an agent cashes money in on account of a bank, it is dealt with as if he were taking money out of his account. Obviously, he can only hand out the cash he has at hand. As cash-in and cash-out transactions are not always balanced in a given period of time, agents might be unable to perform requested transactions. The financial capacities needed for an agent depend on his proximity to a place where he can cash in and out on his account and the delay with which his account will be credited. One way of addressing the problem of agents' financial capacities is to structure the agent network with different levels presenting a graduation of financial capacities. Masteragents can be used who are responsible for managing the cash and electronic-value liquidity requirements of a particular group of agents; ${ }^{32}$ their operations are more challenging in rural areas. In Kenya, some M-PESA agents who are located near to their masteragent's branch can renew their cash two to three times daily while more rural agents do so once a day or once every two days, with over an hour travel time.

Density of the agent network in the bank's areas of operation is a key factor to enable proximity and convenience for the customer base. The economic activity in rural areas generates short travels towards hotspots (markets, high circulation

31 Frederik Eijkman, Jake Kendall, and Ignacio Mas, "Bridges to Cash: the retail end of M-PESA. The challenge of maintaining liquidity for M-PESA Agent Networks", 2010. http://www.cgap.org/gm/document-1.9.49720/Bridging_\%20the_Cash.pdf.

32 A masteragent is a person or business that purchases e-money from an MNO wholesale and then resells it to agents, who in turn sell it to users. Unlike a superagent, masteragents are responsible for managing the cash and electronic-value liquidity requirements of a particular group of agents. See GSMA, "Mobile Money Definitions, Mobile Money for the Unbanked", 2010. http://www.slideshare.net/sarper/mobile-moneydefinitions. 
crossroads etc.) where it is possible to find retail shops, petrol stations and sometimes MFI/banks' branches which can be used as points of services for remote financial services as well as relays for smaller agents located in remote areas.

\section{Setting Up an Own Third-Party Agent Network}

Setting up and managing an agent network is a lot of work, which translates into costs: identification of agents, training, close monitoring to make sure they are handling operations well, control, hot-line for support in case of problems. In building its agent network, a bank will choose one or a mix of the following strategies:

- Rely on pre-existing networks (typically major retail chains, gas-stations networks, post offices or MFIs). The heads of networks typically function as masteragents ${ }^{33}$ and will participate in the supervision of their agents. Masteragents will need to organize the support to their agents' cash withdrawal and deposit needs, either by setting up cash-managing branches or by identifying higher-level agents or banks with whom their agents can deal;

- Select independent retail shops and manage them directly (banks are in a good position to identify such agents among their individual shopkeeper clients);

- Outsource the building and management of chains of agents to third-party agent management companies who sign up, equip, train and maintain agents on the behalf of their client. ${ }^{34}$

\section{Banking Correspondents: A Specific Type of Third-Party Agents}

Some banks use banking correspondents whose role is not limited to cash transactions but who also act as intermediaries authorized to sell some of the bank's products and services. This has proven to be an efficient way of increasing outreach, in Brazil for example. ${ }^{35}$ The main differences between a bank-led mobile banking system and a network of banking correspondents are that (i) the range of outsourced transactions is broader and (ii) banking correspondent networks have usually been set up based on card and POS technology.

Although some regulations allow a significant participation of banking correspondents in the loan process (collection and preliminary processing of loan applications including verification of primary information, financing proposals, dis-

33 Like PEP in Kenya for M-PESA, see Eijkman et al., 2010.

34 Banco Popular in Brazil (the banking correspondent brand of Banco do Brasil) uses companies such as NetCash in Sao Paulo State and the Brasilia Federal District and PagFacil in Pernambuco. Lemon Bank in Brazil has no branches at all and relies on 16 agent management companies (including three that it purchased) to manage the majority of its 5,750 agents. See also Gautam, 2008.

35 See Kumar et al., 2006; Rotman, 2010; and McKay, 2010. 
bursement of small value credit, follow-up for recovery, post-sanction monitoring) ${ }^{36}$ this raises questions as screening of loan applications and loan approval and follow-up are complex processes requiring specific training and inducing a risk for the bank. Delegating them to outside agents would certainly require a strict prior due diligence, sufficient training, and close monitoring and control.

\section{Relevance of Setting up a Bank-Led Mobile Banking System}

The cost of setting up mobile financial solutions and a network of agents from scratch is so high for a single bank that it might be profitable only for the largest ones. ${ }^{37}$ For banks focusing on loans, the investment in such a system is probably not worth it, since only a minor part of the costs related to credit are significantly reduced by mobile banking systems. However, in the perspective of increasing deposits and savings and of developing the range of services, especially considering the high demand for payment and remittance services in rural areas, the investment becomes more attractive. Other considerations are factored in the decision of creating and managing a MB system, including impact on image and differentiation from competitors.

Thus, setting up a bank-led mobile banking system helps to make sure that such a system serves the bank's interests, but it is a very heavy initiative, which results at cost level in reduced transaction costs and increased production costs in a proportion depending on the environment. An idea is being tested to reduce the weight for smaller-sized banks: setting up mobile banking systems used jointly by several banks. These systems can either be centralized and imposed by the monetary authority ${ }^{38}$ or set up by an individual service provider serving several banks. ${ }^{39}$ This type of systems may allow banks to share costs and reach larger volumes while allowing a good adaptation of the system's functionality to financial services needs as they are designed to serve banks' needs in priority. The challenges they face are effectively serving different needs and priorities between different banks, it will be interesting to follow their effective set-up.

36 See Reserve Bank of India, Discussion Paper on Engagement of 'for-profit' Companies as Business Correspondents, http://www.rbi.org.in/scripts/bs_viewcontent.aspx?Id=2234, 2010.

37 See Kumar et al., 2010.

38 The eZwich smartcard-based system was launched by Bank of Ghana in 2008 and usage is compulsory for all banks including rural banks and savings and loans companies; the launch of the Maldives Monetary Authority Project supported by CGAP and World Bank is planned end 2010.

39 The Senegalese Authorities are launching a phone-based mobile banking scheme aimed at increasing outreach of financial services in rural areas, open to all interested MFIs and banks, with the support of KfW. 


\section{Conclusions}

\subsection{Implications of Outsourcing on a Bank's Operations}

\section{From the Use of Third-Party Agents to Tellerless Banking: Impact on a Bank's Costs}

A significant part of the costs of bank branches is related to cash management:

- Physical security infrastructure (safe and strongroom, guards, in some countries bullet-proof windows are also compulsory) as well as general office space for tellers;

- Processes reducing risks linked to cash transactions, which induce specific staff needs (separate teller and accountant, real-time entry in MIS, close supervision by branch manager, specific audit procedures);

- Costs linked to the necessity to maintain cash available;

- Periodic cash transportation;

- Support to illiterate clients for filling out forms.

Therefore, when complete outsourcing of cash transactions is possible, some banks have set-up tellerless offices whose roles are limited to managing the backoffice (issue contracts, collection sheets), receiving clients (for loan applications, account opening, financial advice, signature of loan contracts, financial information, redress for errors) and hosting team meetings. ${ }^{40}$ The reduction in production costs as compared to full-fledged branches makes it possible to set up such offices in areas that do not generate enough activity to support a full-fledged branch including cashier staff and equipment. An organization based on roaming officers will also be much easier to manage and control when officers do not have to handle cash. The idea here is not to work without branches but to work with an alternative type of network. Hence the term "tellerless banking.",41

Thus, outsourcing cash transactions to external agents can completely change the costs of a bank's network by making it possible to use light offices or roaming officers instead of full-fledged branches, or to relieve roaming officers from cash management. This tellerless banking can make services sustainable in sparsely populated areas where a traditional organization could not cover its costs. The right combination of roaming officers, light retail outlets of different types, thirdparty agents, and ATMs will have to be determined based on the characteristics of each local market. ${ }^{42}$ Convenience to the client is what grows the business.

40 This is the model set up by FIDES in FIDES Bank Namibia and planned in their Sénégal Project.

41 Jean-Hubert Gallouet, HORUS-Development Finance, Vice-President.

42 See Opportunity International's experience in Malawi (Campbell et al., 2008). 


\section{Impact of Outsourcing on Outreach}

Outsourcing induces reduced transaction costs for cash transactions for both client and bank. Whereas we have seen that this is the major cost-driver for savings, deposits, payments and remittances, in the case of loans, cash transactions generate only a small part of a bank's transaction costs. Close interaction with LO is essential at all stages of the credit process: loan application assessment, regular monitoring during the loan, and contract enforcement in case of default. Therefore, outsourcing loan repayments to external agents requires reviewing the whole process.

Group lending technology in Kenya provides an interesting example: with external agents available anytime for repayment close to clients' homes, centralizing repayment through a group treasurer actually increases transaction costs for clients instead of reducing them as it used to (treasurer used to mutualism traveling and queuing-related costs). This had led SMEP and FAULU in Kenya to change the repayment process of their group-loans:

- from payment at group meetings in the presence of LO + group treasurer depositing the total repayment at a bank;

- to individual payments at MPESA + brief review at group meetings of the timely repayment of members from receipts.

In such cases where lending is based on group technology, the switch from loan repayment at group meetings to individual loan repayments at external agents needs to be carefully prepared to avoid it weakening repayment discipline. Both Faulu and SMEP had that experience at the beginning of their partnership with M-PESA. This has led other MFIs to use external repayment channels only for individual loans, as for example Tujijenge Tanzania. ${ }^{43}$ Changing loan repayment channel thus needs to be carefully prepared in terms of impact on the MFI's processes.

Whereas in the Kenyan example clients used to be in charge of bringing the cash to a bank to repay their loans, in many cases it is the LO who collects the cash and brings it to the bank. ${ }^{44}$ In these latter cases, it is not primarily the clients' transaction costs that repayment at agents will reduce but instead the bank's transaction costs. Although this might in the end also reduce the clients' transaction costs (reduction in time spent at group meetings, choice of time and place to repay), incentives will probably need to be provided to clients in such cases. Banks may then consider subsidizing the cost for their clients or lowering their interest rates to pass on part of the reduction in transaction costs to their clients. ${ }^{45}$ The impact of the change on the client's transaction costs will thus determine whether a system can be changed easily or not.

\footnotetext{
43 See Kumar et al., 2010.

44 This is the case of well-known Grameen Bank as well as CAURIE Microfinance in Senegal and SafeSave in Bangladesh, for example.

45 See Kumar et al., 2010.
} 
Thus, increase in outreach for lending services will require:

- either increased LO productivity, enabling one LO to reduce the time necessary for each interaction with his clients and thus to increase the number of loans in his portfolio; this is what Faulu and SMEP experienced in Kenya when outsourcing cash transactions but it very much depends on the previous organization of loan management;

- or an increase in the number of loan officers, enabling a branch to cover a larger area.

Thus, the scope of activities to be implemented by third-party agents should not be extended to loans without proper control mechanisms. When part of the loan process is to be outsourced, experience shows that the bank's organisation has to be reviewed in order to keep the close contact between client and LO that is necessary. Moreover, all of the implications of changing the cash-management network in an MFI need to be carefully thought out, especially regarding loan repayments, in order to avoid compromising portfolio quality.

\section{Designing Products Differently: Impact on Quality of Service}

By removing one of the major constraints to product design in rural areas, the feasibility of channeling cash to and from clients at reduced transaction costs opens the possibility of designing products differently: Both savings and credit products can involve more frequent transactions. Loan disbursement can be contemplated in tranches in order to better suit the calendar of the needs of clients ${ }^{46}$ and also reduce unit amounts to put less strain on the cash available with rural agents. Indeed, product design needs to take into account the fact that the unit amount of transactions at an agent's shop will necessarily be capped, both for security and cash management reasons, caps being liable to differ between agents. Therefore agents can only be used for transactions with small enough unit amounts.

Outsourcing cash transactions to external agents thus opens the possibility of designing rural products differently.

\subsection{When Should a Bank Contemplate Launching a Mobile Banking System?}

\section{Relevance of Mobile Banking Strategy}

The mobile banking strategy is only one component of a bank's strategy to reach rural clients. Market needs have to be analyzed, and adapted products and processes have to be defined. As we have seen, whereas outsourcing cash transactions will be a very significant cost reduction mechanism for savings and deposits as

46 This is particularly relevant for agricultural lending that should ideally reflect seasonalities of agricultural production. 
well as for remittance and payment services, it is only a minor part of the costs of credit delivery. And simple SMS-banking is very adapted to improve communication between bank and client. Thus, depending on the bank's strategy for a given market, which itself depends on the unmet needs of this market, mobile banking might or might not be a good complement to increase outreach. In certain environments, "old-fashioned solutions" might be more relevant and successful. These have considerably gained in security from the introduction of ICT and are far from being obsolete. The mobile banking hype is thus definitely not a sufficient reason for engaging in such a heavy project.

To be profitable, a bank's mobile banking strategy needs to include a whole range of services addressing the needs of different market segments (not only those of the rural market). Mobile banking requires costly investments that need to be absorbed by a high volume of activity which can, depending on the context, be generated either by the sole bank with its whole customer base or by the use of a modularized system, based either on an external provider or on one set up by a group of banks.

In a given market a bank might need to offer a number of mobile-banking services, not necessarily the whole array (e.g. SMS-banking or account to account transfers), in order to just keep up with the market. This has to be analyzed on a case by case basis.

When considering technology-driven solutions, a bank should thus consider the type of services to be delivered to clients, model the solution's economy in the bank's given environment and make sure the necessary pre-conditions are in place. In a favorable environment, mobile banking can considerably help to extend the outreach of rural finance, but this requires to define at bank level (i) a comprehensive strategy to reach rural clients (including products, processes, etc.), and (ii) a mobile banking strategy (for both urban and rural areas).

\section{Bank-Related Pre-conditions}

A bank planning to use or set up a mobile banking system including provision of rural and agriculture loans will need to be already successfully offering financial services to rural/agricultural customers. Rural lending is a difficult field and mobile banking will not create the necessary skills.

Introducing mobile banking must be consistent with the bank's strategy and business plan. Financial projections must show sustainability of the project taking into account the following possible advantages:

- Reduce production costs per unit and/or transaction costs, at MFI and/or client levels;

- Reduce congestion in branches;

- Improve satisfaction and retain existing customers;

- Better face competition; 
- Reach new customer segments or new geographic areas, at better conditions than those offered so far, including by the informal financial system;

- Marketing argument (build customer loyalty).

\section{Environment Pre-conditions}

Minimum regulatory conditions must be met, mainly permitting banks to engage third-party retail outlets with minimal financial risks for both banks and their customers, and tiered know-your-customer regulations in line with the possibilities of documentation of rural outlets for low-value transactions. ${ }^{47}$

Another critical element is the existence of potential agents: pre-existence of commercial networks is a favorable element and presence of potential agents of sufficient financial caliber in the region where mobile banking is contemplated is necessary. The bank needs to have a good understanding of the capacities and limits on the agent level.

\subsection{The Role of Government and Donors}

A positive role for the government is in creating an enabling environment, and in particular setting up adapted regulation enabling the use of technology and thirdparty agents while ensuring protection of consumers and of the financial system as a whole. Consumer protection is indeed a major concern to be addressed when regulated institutions outsource operations to non-regulated agents. Main related policy objectives are:

- Protecting client funds held as electronically stored value;

- Ensuring safety and reliability of services;

- Reducing opportunities for agent fraud and other harmful conduct;

- Ensuring clear and effective disclosure;

- Protecting clients' personal information;

- Ensuring clients have knowledge of and access to effective redress and complaint procedures. $^{48}$

Donors and development finance institutions (DFIs) have an important advocacy role by engaging in a dialogue with governments on conducive policies and frameworks for expanding financial services through use of third-party agents, and by facilitating exchange and learning on lessons and good practices.

47 See Alexandre et al., 2010.

48 See Denise Dias and Katharine McKee, "Protecting Branchless Banking Consumers: Policy Objectives and Regulatory Options", CGAP Focus Note No. 64, 2010. 
- Using technology for expanding outreach in rural areas is a new field presenting high risk and uncertainties for banks. In this context, it also makes sense for donors to support pilot projects that can build reference for future replication. In a context where mobile-banking is very much in fashion, an important contribution donors can make to its healthy development is helping banks gain a comprehensive understanding of stakes and issues.

\section{References}

Alexandre, C., Mas, I., Radcliffe, D. (2010) Regulating New Banking Models that Can Bring Financial Services to All, 1 August 2010, http://ssrn.com/abstract= 1664644 (last accessed 16 October 2010).

Andersen, E. (1985) The Salesperson as Outside Agent or Employee: a Transaction Cost Analysis. Marketing Science 4(3).

Berger, E., Opportunity International (2009) Case Study, Overcoming Back-end Barriers: Opportunity International and Bank Switching Solutions, http://www. opportunity.org/wp-content/uploads/2010/07/Switching-Solutions.pdf.

Breloff, P., Tarazi, M. (2010) Nonbank E-Money Issuers: Regulatory Approaches to Protecting Customer Funds. CGAP Focus Note No. 63.

Campbell, B., Kalanda, A.-A. (2008) Banking Rollout Approaches to Rural Markets - Opportunity International Bank of Malawi. OI White Paper $\mathrm{N}^{\circ} 8$.

CGAP Technology Program (2008) Notes on Regulation of Branchless Banking in Brazil.

Central Bank of Kenya (2010) Guidelines for Agency Banking.

Chipchase, J. (2010) Mobile banking: Agents as mediators.

http://technology.cgap.org/2010/06/04/mobile-banking-agents-asmediators/\#more-2630.

Dias, D., McKee, K. (2010) Protecting Branchless Banking Consumers: Policy Objectives and Regulatory Options. CGAP Focus Note No. 64.

Eijkman, F., Kendall, J., Mas, I. (2010) Bridges to Cash: the retail endof M-PESA. The challenge of maintaining liquidity for M-PESA Agent Networks.

Firpo, J. (2009) E-Money - Mobile Money - Mobile Banking - What's the Difference?, http://psdblog.worldbank.org/psdblog/2009/01/emoney-mobile-moneymobile-banking-whats-the-difference.html.

GSMA (2010) Mobile Money Definitions, Mobile Money for the Unbanked.

Ivatury, G., Mas, I. (2008) The Early Experience with Branchless Banking, CGAP Focus Note No. 46. 
Ivatury, G., Lymann, T., Staschen, S. (2006) Use of Agents in Branchless Banking for the Poor: Rewards, Risks and Regulation. CGAP Focus Note No. 38.

Kumar, A., Nair, A., Parsons, A., Urdapilleta, E. (2006) Expanding Bank Outreach through Retail Partnerships, Correspondent Banking in Brazil, World Bank Working Paper No.85.

Kumar, K., McKay, C., Rotman, S. (2010) Microfinance and Mobile Banking: The Story So Far. CGAP Focus Note No. 62.

Letort, J.-M. (2010) How to make your MM project profitable? Greenwich Consulting, GSMA presentation.

Mas, I. (2009) The Economics of Branchless Banking. Innovations 4(2):57-75.

McKay C., Pickens, M. (2010) Branchless Banking 2010: Who's Served? At What Price? What's Next? CGAP Focus Note No. 66.

McKay, C. (2010) From rural outpost to boomtown: how banking services transformed a town in the Amazon, CGAP technology blog, http://technology.cgap. org/2010/01/28/from-rural-outpost-to-boomtown-how-bankingservices-trans formed-a-town-in-the-amazon/.

Mwaura, K., Okuttah, M. (2010) Equity’s deal with Orange tilts banking landscape. posted Thursday, November 11th 2010 at 19:43 on Business Daily, http:/www. businessdailyafrica.com/Corporate\%20News/Equitys $\% 20$ deal $\% 20$ with $\% 252$.

Munford, M. (2010) M-Paisa: Ending Afghan Corruption, one Text at a Time.

North, D. (1999): Institutions, Institutional Change and Economic Performance.

Pickens, M., Porteous, D., Rotman, S. (2009) Scenarios for Branchless Banking in 2020. CGAP Focus Note No. 57, www.cgap.org/gm/document-1.9.40599/ FN57.pdf (last accessed 16 October 2010).

ProCredit Bank Moldova (2009) Annual Report 2009, www.procreditholding. com/front_content.php?idcat=26 (last accessed 16 October 2010).

Reille, X. (2006) Les technologies de distribution, MFT 2006, Turin "Microfinance et technologie".

Reserve Bank of India (2006) Circular Financial Inclusion by Extension of Banking Services - Use of Business Facilitators and Correspondents, http://rbi.org.in/ scripts/BS_CircularIndexDisplay.aspx?Id=2718.

Reserve Bank of India (2010) Discussion Paper on Engagement of 'for-profit' Companies as Business Correspondents, http://www.rbi.org.in/scripts/bs_viewcontent.aspx? $\mathrm{Id}=2234$.

Rotman, S. (2010) Branchless banking in Brazil: making it work for small merchants, CGAP technology blog, http://technology.cgap.org/2010/02/05/branchless-banking-inbrazil-making-it-work-for-small-merchants/. 
Rutherford, S. (2010) New Paradigms in Microfinance Portfolios of the Poor microfinance from the perspective of the poor, adapting to clients. Boulder: MFT.

Tarazi, M. (2010) The Logic Behind Branchless Banking, CGAP, Boulder Microfinance Institute.

Whelan, S., with contributions from CGAP Staff and exchange, LLC (2004): Automated Teller Machines, CGAP IT Innovations Series, http://www.cgap.org/ $\mathrm{p} / \mathrm{site} / \mathrm{c} / \mathrm{template.rc/1.9.2757.}$ 